дискретної математики у мережі Інтернет.

Розділ «Оголошення» відображає оголошення викладача у текстовому форматі, переглядати цей розділ мають можливість тільки зареєстровані користувачі.

Розділ «Публікації» надає можливість користувачам переглядати публікації інших студентів та оцінювати їх за десятибальною шкалою. На головній сторінці у випадаючому меню входу є можливість додавати свої публікації на сайт. Після перегляду публікації адміністратором і її ухвалення, вона потрапляє у розділ «Публікації», де вже доступна для інших користувачів.

Отже, застосування комп’ютерів як засобів навчання дискретної математики створює передумови для вдосконалення традиційних методик навчання. Перевага використання комп’ютера, як засобу навчання, в порівнянні з іншими технічними засобами навчання полягає в тому, що він одночасно є інформаційним, контролюючим і навчальним засобом, що $\epsilon$ особливо важливим в умовах особистісно зорієнтованої системи навчання дискретної математики.

Спрямованість на професійно особистісне самовизначення, самоорганізацію, самореалізацію як найважливіші компоненти саморозвитку особистості, повинно зайняти провідне місце в навчально-виховному процесі ВНЗ, зокрема - в навчанні дискретної математики у вищому навчальному закладі.

\title{
Література
}

1. Інформаційні технології і засоби навчання / [за ред. В. Ю. Бикова, Ю. О. Жука]. Київ : Атіка, 2005. - 272 с. 2. Кронбергская декларация о будущем процессов приобретения и передачи знаний / UNESCO High Level Group of Visionaries on Knowledge Acquisition and Sharing. - Кронберг, 2007 [Электронный ресурс]. - Режим доступа : http://www.ifap.ru/library/ book199.pdf. 3. Литвиненко М. В. Структурно-функциональная модель индивидуальной траектории обучения в условиях информатизации образования : автореф. дисс. на соискание ученой степени докт. пед. наук : спец. 13.00.01 «Общая педагогика, история педагогики», 13.00.02 «Теория и методика обучения и воспитания» / М. В. Литвиненко. - Москва, 2007. 46 с. 4. Луговий В. I. Інформаційне забезпечення вищої школи України / В. Луговий, Н. Халікян // Вища освіта України. - 2007. - № 3. - С. 48-51.

УДК 371.91(07)

Олександр Надтока, Тетяна Мартинюк

\section{ЗАСТОСУВАННЯ ДІЯЛЬНІСНОГО ПІДХОДУ ЯК ОДНОГО 3 АСПЕКТІВ ДОСЛІДЖЕННЯ МЕТОДИКИ НАВЧАННЯ ГЕОГРАФІЇ}

Надтока О. Ф., Мартинюк Т. С. Застосування діяльнісного підходу як одного 3 аспектів дослідження методики навчання географії.

У статті розглядаються питання, що стосуються проблематики методичних засад навчання географії на основі діяльнісного підходу. Вони спираються на переосмислення ролі вчителя й учня у процесі навчання географії в загальноосвітніх навчальних закладах. Результатами впровадження діяльнісного підходу в навчанні $є$ набуття учнями досвіду практично-дослідної діяльності, формування особистісного розвитку через власну траєкторію навчання; розвиток емоційно-ціннісного ставлення до географічного пізнання; формування в учнів здатності до самоосвіти, критичного і прогностичного мислення, а на його основі - ключових та предметної компетентностей. Усе зазначене вище зумовлене необхідністю адекватного відображення відповідної географічної картини світу 
у свідомості учня.

Ключові слова: географічна картина світу, діяльнісний підхід у навчанні, змістовий і процесуальний компоненти навчання географії, компетентнісне навчання, особистісно зорієнтоване навчання.

Надтока А. Ф., Мартынюк Т. С. Применение деятельностного подхода как одного из аспектов исследования методики обучения географии.

В статье рассматриваются вопросы, касающиеся проблематики методических основ обучения географии на основе деятельностного подхода. Они базируются на переосмыслении роли учителя и ученика в процессе обучения географии в общеобразовательных учебных заведениях. Результатами внедрения деятельностного подхода в обучении является приобретение учащимися опыта практическиисследовательской деятельности, формирование личностного развития через собственную траекторию обучения, развитие эмоционально-ценностного отношения к географическому познанию; формирование у учащихся способностей к самообразованию, критического и прогностического мышления, а на его основе - ключевых и предметной компетенций. Все вышеперечисленное обусловлено необходимостью адекватного отражения соответствующей географической картины мира в сознании ученика.

Ключевые слова: географическая картина мира, деятельностный подход в обучении, содержательный и процессуальный компоненты обучения географии, компетентностное обучение, личностно ориентированное обучение.

Nadtoka O. F., Martyniuk T. S. Application of activity approach as one the aspects of study of geography teaching methods.

The article deals with issues relating to the problems of methodological principles of geography teaching based on activity approach. They are based on rethinking the role of teachers and students in geography teaching at comprehensive schools. The results of activity approach implementation in education are gain in experience of practical and research activities, the formation of personal development through its own learning path, the development of emotional and value attitude to geographical knowledge; development of key and subject competences on the basis of students' ability to self-education, critical and time perspective thinking. All the above mentioned is caused by need of adequate reflection of the corresponding geographical picture of the world in student's consciousness.

Key words: geographical picture of the world, activity approach to training, semantic and procedural components of geography teaching, competence training, person centered training.

Зміни в сучасній системі освіти значною мірою викликані тим, що учень XXI століття вже належить до абсолютно нового, за приналежністю до соціуму, типу людини - людина інформаційна, оскільки значний проміжок часу вона фактично перебуває в межах медіасередовища. Тому це стало одним із чинників парадигмальних змін в освіті, виражених переходом від знаннєвої до особистісно зорієнтованої парадигми та широким упровадженням компетентнісного навчання. Такий вектор розвитку освіти спричиняє низку змін у підготовці та проведенні навчальних занять. Повною мірою це стосується й географії як одного із базових навчальних предметів, соціальний запит населення на який виражено через участь випускників загальноосвітніх навчальних закладів (ЗН3) у зовнішньому незалежному оцінюванні (ЗНО). Останнім часом усе це значною мірою вплинуло на 
методику навчання географії. Основні напрямки цих змін виявляються у:

- зміні ролі вчителя в навчанні (він перестає бути ретранслятором знань, а стає наставником, порадником і організатором навчального процесу);

- орієнтації учня не лише на здобуття знань, а й на вміння їх використовувати в реальних життєвих ситуаціях та формуванні ключових і предметних компетентностей;

- зміні ролі учня в навчанні, коли він не лише сприймає певні блоки знань, а формує власну предметну траєкторію навчання (зокрема, географії);

- збільшенні обсягів самостійної роботи учнів у рамках навчального заняття;

- збільшенні обсягів застосування педагогами активних та інтерактивних методів навчання;

- технологізації процесу навчання [9].

Усе це $є$ вельми актуальним на тлі загальнопедагогічних тенденцій, коли змінюються умови функціонування самої освіти у глобалізованому світі. Адже іï характер і методичні особливості реалізації в знаннєвому суспільстві, в інформаційному просторі надто відрізняються від класичних підходів. Тому предметна методика навчання спрямовується на реалізацію важливих освітніх завдань, зокрема через зміну підходів у реалізації змісту навчальних предметів, у тому числі й географії.

Зазначені тенденції розвитку освітньої системи України відображені в Державному стандарті базової і повної загальної середньої освіти, де вказується на необхідність здійснення навчання географії на основі компетентнісного, особистісно зорієнтованого, діяльнісного і краєзнавчого підходів [1]. У такий спосіб цей основоположний освітній документ визначає діяльнісний підхід серед основних у навчанні, адже він вимагає не лише сприймати та ретранслювати навчальний матеріал, а й осмислювати його у процесі навчальної діяльності, пропускаючи його через набутий суспільний досвід учня й реалізуючи у здобутих уміннях, навичках та подальших учинках [6].

Наукові пошуки в галузі предметної методики багато в чому пов’язані з розробкою форм та методичних підходів реалізації шкільних географічних курсів. Вони посідають чільне місце в роботах з методики навчання географії О. Браславської, Л. Вішнікіної, С. Коберніка, В. Корнєєва, М. Криловця, Л. Круглик, О. Надтоки, Т. Назаренко, Л. Покась. M. Топузова, $\quad$ О. Топузова, $\quad$ Б. Чернова, $\quad$ I. Шоробури, $\quad$ А. Шуканової $\quad$ та $\quad$ інших вітчизняних науковців.

У сучасній методиці навчання географії питання використання діяльнісного підходу в навчанні висвітлені ще не досить повно, проте вони є в окремих публікаціях. Зокрема, в Концепції географічної освіти в основній школі зазначається, що учень ЗНЗ діє як суб’єкт предметної діяльності, а для успішного сприйняття й використання наукового знання йому необхідно оволодіти основами наукової діяльності, тобто стати суб’єктом рефлексивної діяльності. Відповідно до цього, одним із завдань сучасної методики навчання географії $\epsilon$ формування в учнів загальнонавчальних умінь, які з уміння вчитися трансформуються в уміння досліджувати. Це $\epsilon$ новим кроком як $\mathrm{y}$ навчанні, так $\mathrm{i}$ в психічному розвитку особистості.

Важливим $є$ погляд на цю проблему з точки зору дидактики, згідно з якою розвиток дослідницьких умінь забезпечує евристичність, софійність, особистісну цінність учіння та $є$ базою формування наукового світогляду учнів ЗНЗ. В основній школі практичне втілення теоретичних знань розвиває інтелект особистості, допомагає впевнитись у можливості розв’язувати складні життєві й наукові задачі самостійно, дає змогу зрозуміти специфіку 
професій, пов’язаних з географією [4, с. 33].

Слід зазначити, що ці положення знайшли своє відображення в підходах до структурування навчального змісту географії. Орієнтація на використання діяльнісного підходу $є$ однією 3 особливостей оновлених навчальних програм 3 географії (2015р.), акцентом змін яких стало розвантаження та фундаменталізація навчання в основній школі відповідно до оновленого Державного стандарту.

Meта cmammi: розкрити один з аспектів розвитку методики навчання географії необхідність практичного застосування діяльнісного підходу в навчанні географії. Актуальність таких методичних новацій зумовлена потребами інформаційного суспільства. Окрім цього, у статті підкреслюється світоглядне значення географії як важливого шкільного предмета, соціальний запит, на який можна відслідковувати через систему ЗНО.

Діяльність - це активність людини, що має усвідомлюваний характер і спрямована на досягнення поставленої мети, що визначається потребою.

У житті людини діяльність відіграє вагому роль, здійснюючи низку важливих позитивних функцій (рис. 1.) [7].
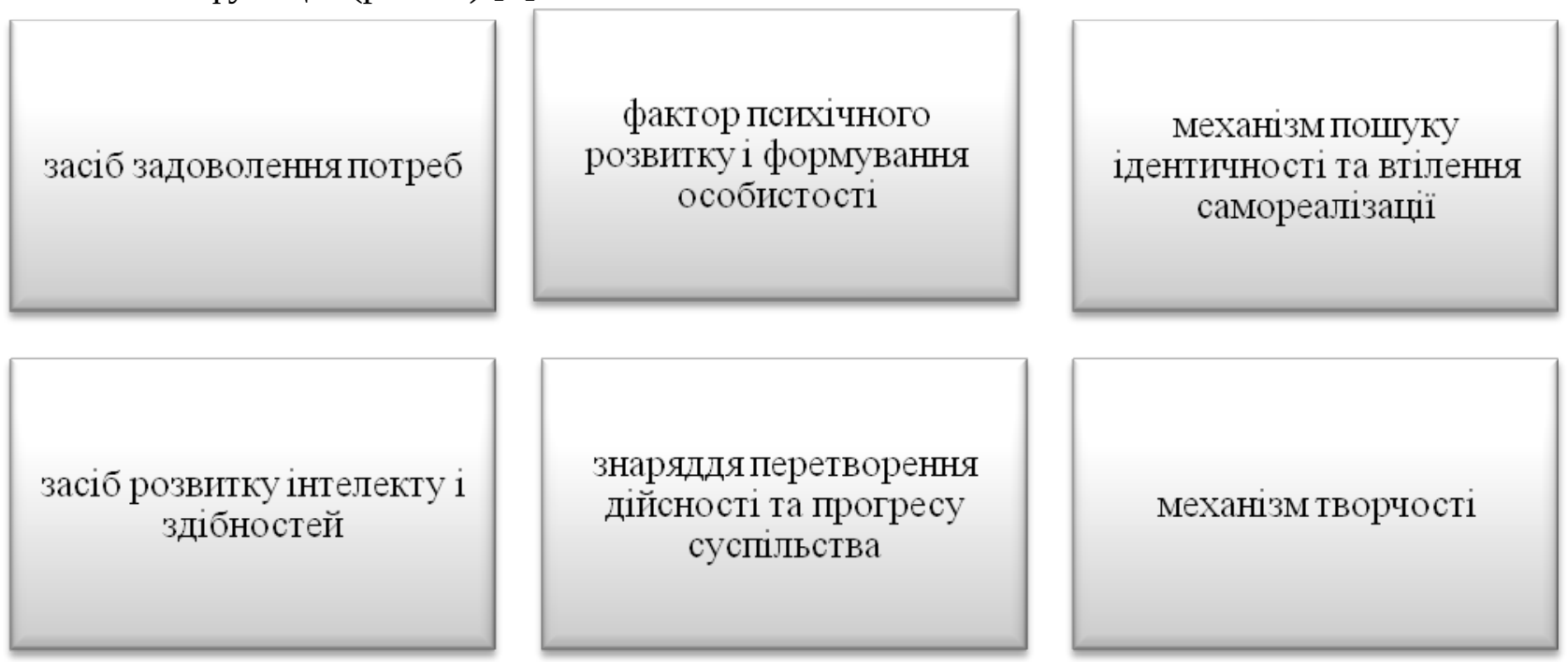

Рис. 1. Функції діяльності

Діяльнісний підхід в освіті - це методологічний базис, на якому будуються різні системи розвивального навчання або освіти зі своїми конкретними технологіями, прийомами, теоретичними особливостями. Існуюча дидактична система Я. Коменського, не вичерпала своєї значущості, разом з тим вона не дозволяє ефективно здійснювати розвивальну функцію освіти. У роботах Л. Занкова, В. Давидова, П. Гальперіна, та інших педагогів-науковців і практиків на основі педагогічної прогностики сформульовані нові дидактичні вимоги, які вирішують сучасні освітні завдання з урахуванням запитів майбутнього. Зокрема, в навчанні географії виокремлюються два системних аспекти:

- взаємопоєднані змістовий і процесуальний компоненти навчання географії;

- навчання (діяльність учителя) та учіння (діяльність учня) географії, які перебувають у нерозривному зв’язку і взаємодії.

Єдність змістового і процесуального компонентів навчання географії розглядається у взаємопоєднанні: змісту шкільної географії та власне процесу навчання іiї. Ці компоненти утворюють цілісну систему й визначають одне одного. Між компонентами, які утворюють систему, як правило, установлюються певні відношення та зв’язки, які мають бути настільки 
тісними, що зміна одного з них викликає зміну інших, а також провокує зміну системи в цілому. Саме наявність такої тісної взаємодії вказує на її цілісність [3]. Зі сказаного можна зробити певні узагальнення. По-перше, зміст утілюється в різних формах навчальнопізнавальної діяльності. По-друге, зміст шкільної географії можна виокремити від такої діяльності лише задля його аналізу й конструювання [5].

Зазначивши єдність змістового і процесуального компонентів навчання географії, укажемо на роль діяльнісного підходу у формуванні географічних уявлень та знань учнів ЗНЗ. Географічні уявлення учнів виникають у результаті цілеспрямованої діяльності вчителя, яка передбачає такі етапи, як:

1) мотивація навчально-пізнавальної діяльності учнів і конкретизація завдань, що стоять перед ними (зацікавлення школярів географічними об’єктами, процесами та явищами, які вивчаються, чіткі рекомендації з навчальних дій);

2) створення цілісних образів географічних об’єктів вивчення на основі чуттєвого сприйняття учнів за допомогою як ілюстративно-демонстраційних, так i вербальних прийомів навчання;

3) засвоєння уявлень щодо об’єктів вивчення через усвідомлення головних ознак і особливостей цих об’єктів;

4) порівнювання ознак чи властивостей низки географічних об’єктів, процесів і явищ 3 виявленням у них найсуттєвіших особливостей;

5) оперування уявними образами без споглядання об’єктів вивчення та/або їхніх замінників, інформаційних матеріалів тощо;

6) закріплення уявлень у процесі їхнього застосування для розв'язання навчальних завдань (позначення на контурній карті, створення асоціативних малюнків, здійснення уявних мандрівок тощо) [2].

Формування теоретичних знань учнів ЗНЗ відбувається іншим чином. Суттєвим кроком у розв'язанні проблеми розвитку логічного пізнання учнів $є$ виокремлення основних понять, термінів, закономірностей тощо, що відображають специфіку змісту сучасних шкільних курсів фізичної й економічної географії. Фактичний матеріал стає цінним тоді, коли його логічно систематизовано й підпорядковано провідним поняттям і теоріям, що дає змогу цілеспрямовано - від теми до теми, від курсу до курсу - ефективно підтримувати процес пізнання учнів [8].

Теоретичні географічні знання поділяються на такі види: географічні гіпотези й теорії, поняття, причинно-наслідкові зв’язки та закономірності.

Географічні поняття характеризуються певним змістом і обсягом, які, зрозуміло, істотно взаємопов'язані між собою. При цьому зміст- це сукупність істотних ознак, взаємозв’язки між якими утворюють структуру географічного поняття, а обсяг - це кількість географічних об’єктів вивчення, які охоплюються цим змістом.

Географічні поняття за змістом і обсягом поділяють на загальні й одиничні (часткові). Загальні поняття, у свою чергу, диференціюються на загальнонаукові й загальногеографічні. До загальнонаукових понять належать ті, які $є$ усталеними в різних науках, економіці й соціальній галузі. Загальногеографічні ж поняття поділяють на групи, вони відображають:

1) фізико-географічні об’єкти вивчення;

2) економіко-географічні об'єкти вивчення;

3) зв’язки між елементами довкілля та довкіллям і економікою;

4) географічну карту й способи просторового відображення природних і соціальноекономічних об'єктів на ній тощо [2]. 
У всіх випадках учитель географії повинен чітко диференціювати географічні поняття за вищенаведеними ознаками, добираючи різні методи, методичні прийоми, форми й засоби навчання для формування цих понять.

Оволодіння учнями навчальними уміннями (працювати з текстом й ілюстраціями підручника, конспектувати шкільну лекцію, здійснювати бібліографічний пошук, працювати з комп’ютером, планувати свою навчальну діяльність тощо) істотно впливає на глибину і міцність засвоєння географічних знань школярами та надає їм змогу раціонально витрачати час на виконання самостійної роботи в класі, удома тощо [2].

Чільне місце в навчанні географії посідає формування прикладних умінь, що значною мірою поєднані з отриманням географічної інформації з різноманітних джерел знань і її використанням. Доречно зазначити, що у шкільних курсах географії більша частина таких умінь формується під час виконання певних практичних робіт [2].

Підсумовуючи сказане, зазначимо, що під діяльнісним розвитком учнів у процесі навчання географії в ЗНЗ ми розуміємо:

1) набуття учнями досвіду практично-дослідної діяльності, формування свідомого керування особистісним розвитком через реалізацію власної траєкторії навчання;

2) розвиток емоційно-ціннісного ставлення до географічного пізнання;

3) формування в учнів здатностей до самоосвіти, критичного і прогностичного мислення, а на його основі - ключових і предметної компетентностей [3].

Географічне бачення світу - це історично зумовлений цілісний образ довкілля, який грунтується на знаннях про природу Землі, ї̈ населення, світову економіку та їхню взаємодію. Його еволюція у свідомості учня є важливою ланкою у формуванні предметної географічної компетентності. Усе це зумовлюється взаємодією індивідуального сприйняття учнями довкілля і сучасного науково-географічного інтегрованого відображення світу, 3 яким вони знайомляться на заняттях з географії. Отже, процес навчання географії забезпечує поступовий перехід від побутового бачення світу до географічного, а діяльність учителя спрямовується на організацію навчально-пізнавальної діяльності учнів, що забезпечить такий перехід.

Методика навчання географії на сучасному етапі iї розвитку розв’язує важливу проблему - формування географічної картини світу в учнів ЗНЗ, включаючи такий важливий компонент, як використання нових підходів у навчальній діяльності, зокрема й діяльнісного. Їх системне використання стимулює застосування активних та інтерактивних методів навчання й нових освітніх технологій.

Методика навчання географії за умови використання діяльнісного підходу в сучасних ЗНЗ повинна гармонійно поєднувати педагогічну взаємодію вчителя та учня, коли діяльність постає формою активного, творчого ставлення людини до навколишнього світу та до самої себе з метою таких змін, перетворень, які б полегшували й прикрашали ії життя. Діяльність передбачає мету, смисл, предмет, засіб, процес діяльності (здійснення мети).

\section{Література}

1. Державний стандарт базової і повної загальної середньої освіти [Електронний ресурс]. - Режим доступу : http:// www.mon.gov.ua/images/files /doshkilna-cerednya/serednya/ derzh-standart/post_derzh_stan.doc 2. Дидактика географії : монографія / В. М. Самойленко, О. М. Топузов, Л.П.Вішнікіна, О. Ф. Надтока, І. О. Діброва. - Київ : Педагогічна думка, 2014. - 586 с. 3. Карташова Л. А. Нові підходи до проектування педагогічних програмних засобів та їх застосування / Л. А. Карташова, В.В.Лапінський // Материалы Междунар. конф. «Стратегия качества в промышленности и образовании» (3-10 июня 2005 г., Варна, 
Болгария). - Дніпропетровськ ; Варна : Пороги, 2005. - C. 287-290. 4. Концепція географічної освіти в основній школі:проект / Інститут педагогіки НАПН України/ О. М. Топузов, О. Ф. Надтока. Л. П. Вішнікіна. А. С. Доброскок та ін. - Київ : Педагогічна думка, 2014 - 30 с. 5. Кремень В. Г. Філософія людиноцентризму в стратегіях освітнього простору / В. Г. Кремень. - Київ : Педагогічна думка, 2009. - 520 с. 6. Кремень В. Г. Філософія національної ідеї. Людина. Освіта. Соціум / В. Г. Кремень. - Київ : Грамота, 2010. - 576 с. 7. Мацкевич В. Дослідження діяльністю [Текст] / В. Мацкевич // Питання методології. - Лієпая, 1993. - 198 с. 8. Методика обучения географии в средней школе: учебное пособие [для студентов пед. институтов по географ. спец.]/ под ред. Л. М. Панчешниковой. - Москва : Просвещение, 1983. - 320 с. 9. Надтока О. Ф. Зміна ролі вчителя географії в медіасередовищі сучасного навчального заняття / О.Ф. Надтока, Т. С. Мартинюк // Комп’ютер в школі та сім’ї. - Київ, 2015. -№ 2. - С. 30-36.

УДК 378.811 .1

Алла Нікітіна

\section{ФОРМУВАННЯ ДОСЛІДНИЦЬКОЇ КОМПЕТЕНТНОСТІ МАГІСТРАНТІВ- ФІЛОЛОГІВ ЗАСОБАМИ ДИСКУРСУ}

Нікітіна А. В. Формування дослідницької компетентності магістрантів-філологів засобами дискурсу.

У статті визначено наукові засади формування дослідницької компетентності магістрантів-філологів - майбутніх викладачів української мови і літератури, дослідників української філології, зокрема уточнено поняття «дослідницька компетентність магістрантафілолога»; проаналізовано часткові положення методології педагогічного дискурсу та визначено їх роль як засобу формування дослідницької компетентності магістрантів-філологів.

Ключові слова: дослідницька компетентність, магістранти-філологи, педагогічний дискурс, методологія дискурсу.

Никитина А. В. Формирование исследовательской компетентності магистрантовфилологов средствами дискурса.

В статье определены научные принципы формирования исследовательской компетентности магистрантов-филологов - будущих преподавателей украинского языка и литературы, исследователей украинской филологии, в частности уточнено понятие «исследовательская компетентность магистранта-филолога»; проанализированы частичные положения методологии педагогического дискурса и определена их роль как средства формирования исследовательской компетентности магистрантов-филологов.

Ключевые слова: исследовательская компетентность, магистранты-филологи, педагогический дискурс, методология дискурса.

Nikitina A. V. Research competence formation of master' of philology by means of discourse.

The article includes scientific principles of research competence formation of masters of philology - the future teachers of Ukrainian language and literature, researchers of Ukrainian philology. Also, the definition of "research competence of master of philology" is precised; the partial aspects of methodology of the pedagogical discourse are analyzed and their roles as the 